\title{
Algılanan Yönetici Desteği ile Örgütsel Sinizm Arasındaki İlişkide Lider-Üye Etkileşiminin Aracılık Etkisi $^{1}$
}

\author{
DOI: 10.26466/opus.584036 \\ *
}

\begin{abstract}
Zülfi Umut Özkara* - Aynur Taş* - Belgin Aydıntan ${ }^{* * *}$
* Öğrr. Gör. Dr., Ankara Hacı Bayram Veli Üni., Ban. ve Sig. Y.O, Bankacılık Böl., Ankara/Türkiye E-Posta: umut.ozkara@hbv.edu.tr ORCID: 0000-0002-5031-808X ** Dr. Öğr. Üyesi, Hakkari Üniversitesi, İ.İ.B.F, İşletme Bölümü, Hakkari / Türkiye E-Posta: aynurtas@hakkari.edu.tr ORCID: 0000-0001-6810-8358 *** Prof. Dr., Ankara Hacı Bayram Veli Üniversitesi, İ.İ.B.F, İşletme Bölümü, Ankara / Türkiye E-Posta: $\underline{\text { belgin.aydintan@hbv.edu.tr }}$ ORCID: $\underline{0000-0002-9057-4336}$

\section{Öz}

Bu çalışmada; algılanan yönetici desteği ile örgütsel sinizm arasındaki ilişkide lider-üye etkileşiminin aracılık etkisi araştırılmıştır. Araştırmanın veri seti; Ankara'daki bir kamu kurumunun merkez teşkilatında çalışan mühendislerden elde edilen 215 anketten oluşmaktadır. Elde edilen veriler, SPSS 24 ve AMOS 24 programları ile analiz edilmiştir. Çalışma kapsamında; geçerlilik, güvenilirlik, Pearson korelasyon, yapısal eşitlik modellemesi ve Sobel testi analizleri gerçekleştirilmiştir. Analiz sonuçlarına göre, çalışmaya katılanlar bakımından algılanan yönetici desteğgi lider-üye etkileşiminin kalitesini pozitif ve anlamlı bir şekilde doğrudan etkilemektedir. Lider-üye etkileşiminin kalitesi de örgütsel sinizimi negatif ve anlamlı bir şekilde doğrudan etkilemektedir. Diğer taraftan algilanan yönetici desteği örgütsel sinizmi, sadece lider-üye etkileşiminin kalitesi üzerinden negatif ve anlamlı bir şekilde dolaylı olarak etkileyebilmektedir. Bu durumda, algılanan yönetici desteğgi ile örgütsel sinizm arasındaki ilişkide liderüye etkişiminin tam aracı değişken rolü bulunmaktadır. Bu çalışmada; algılanan yönetici desteği ve lider-üye etkileşiminin kalitesi düzeylerindeki artışın örgütsel sinizm düzeyi üzerindeki azaltıcı etkileri yoluyla örgütsel sinizmin örgüt üzerindeki zarar verici etkilerini düşürmenin ve böylece örgüte katkı sağlamanın mümkün olduğu sonucuna ulaşılmaktadır.

Anahtar Kelimeler: Algılanan yönetici desteği, Lider-üye etkileşimi, Örgütsel sinizm, Sosyal değişim kuramı.

\footnotetext{
${ }^{1}$ Bu çalışma, 02-04 Mayıs 2019 tarihlerinde Osmaniye'de gerçekleştirilen 18. Uluslararası İşletmecilik Kongresi'nde sözlü bildiri olarak sunulmuştur.
} 


\title{
The Mediating Effect of Leader-Member Exchange in the Relationship Between Perceived Supervisor Support and Organizational Cynicism
}

\begin{abstract}
This study investigates the mediating effect of leader-member exchange in the relationship between the perceived supervisor support and the organizational cynicism. 215 eligible questionnaires obtained from engineers working in the central organization of a public institution in Ankara have formed the data set of the research. These data obtained have been analyzed through SPSS 24 and AMOS 24 softwares. In this study; validity, reliability, Pearson correlation, structural equation modeling and Sobel test have been employed. According to the analysis results in terms of participants in this study, the perceived supervisor support has a direct positive and significant effect on the quality of leader-member exchange. The quality of leader-member exchange also has direct negative and significant effect on the organizational cynicism. On the other hand, the perceived supervisor support has an indirect negative and significant effect on the organizational cynicism only through the quality of leader-member exchange. In this case, the leader-member exchange is a full mediating variable in this relation. It is concluded that it is possible to reduce the damaging effects of organizational cynicism on the organization and thus contribute to the organization by reducing the level of organizational cynicism through the increase in levels of the perceived supervisor support and the quality of leader-member exchange.
\end{abstract}

Keywords: Perceived supervisor support, Leader-member exchange, Organizational cynicism, Social exchange theory 


\section{Giriş}

Bu çalışmanın temel amacı; algılanan yönetici desteği ile örgütsel sinizm arasındaki ilişkide lider-üye etkileşiminin aracılık etkisini araştırmaktır. Algılanan yönetici desteği, lider-üye etkileşimi ve örgütsel sinizm konuları hakkında örgütsel davranış alanında hem yerli hem de yabancı literatürde çok sayıda yayın bulunmaktadır. Literatürde; algılanan yönetici desteği ve lider-üye etkileşiminin kalitesi örgüte katkı sağlayan, örgütsel sinizm ise örgüte zarar veren unsurlar olarak görülmektedir. Bu bağlamda, çalışma kapsamında; "algılanan yönetici desteği ve lider-üye etkileşiminin kalitesi düzeylerindeki artışın örgütsel sinizm düzeyi üzerindeki azaltıcı etkileri yoluyla örgütsel sinizmin örgüt üzerindeki zarar verici etkilerini düşürmek ve böylece örgüte katkı sağlamak mümkün müdür?" sorusuna cevap aranmaktadır.

Algılanan yönetici (lider) desteği ile çevre yanlısı davranış (pro-environmental behavior) (Gkorezis, 2015) ve çalışanların iş performansı (Akkoç, Çalışkan, Uçak ve Özalp, 2013; Karayel, 2016) değişkenleri arasındaki ilişkilerde lider-üye (yönetici-ast) etkileşiminin aracılık etkisinin incelendiği literatürdeki çalışmalar tespit edilmiştir. Bu çalışmada, diğer çalışmalardan farklı bir şekilde araştırma modelinde sonuç değişkeni olarak örgütsel sinizm bulunmaktadır.

Bu çalışmanın Sosyal Değişim Kuramı'na (Social Exchange TheoryBlau, 1964) dayandığı ifade edilebilir. Sosyal Değişim Kuramı, Karşılıkl1lık Normu'nu (The Norm of Reciprocity- Gouldner, 1960) esas almaktadır. Setton, Bennett ve Liden (1996)'ya göre; yönetici ile çalışan arasındaki olumlu ve faydalı eylemler taraflar arasında zorunluluk hissi yaratarak yüksek kalitede değiş-tokuş ilişkisinin oluşmasını sağlamaktadır. Çalışma çerçevesinde; çalışanların yöneticilerinden bilgisel, duygusal ve maddi anlamda destek aldıklarına dair algılarının artması durumunda, yöneticiast arasındaki karşılıklı ilişkinin yani etkileşimin kalitesinin yükselmesi ve böylece çalışanların örgütlerine karşı sinik yani olumsuz tutumlarının azalması beklenmektedir.

Çalışma kapsamında; araştırma modelinin kurulması ve hipotezinin geliştirilmesi amacıyla algılanan yönetici desteği, lider-üye etkileşimi ve örgütsel sinizm konularına ilişkin teorik bilgilere ve bu değişkenler arasındaki ilişkilerin araştırıldığı ampirik çalışmalara yer verilmektedir. 


\section{Algılanan Yönetici Desteği}

Literatürde; algılanan yönetici desteğine ilişkin farklı tanımlar bulunmaktadır. Yönetici desteği; "yöneticilerin, çalışanlarının örgüte yaptıkları katkılara değer vermesi ve onlar önemsemesi düzeylerine dair çalışanların inançları" şeklinde tanımlanabilir (Pohl ve Galletta, 2016, s.62). Diğer bir tanıma göre, yönetici desteği; "yöneticilerin çalışanlarına destek olması, onlara ilgi göstermesi, onları amaçları başarmaları doğrultusunda cesaretlendirerek motive etmeleridir" (Babin ve Boles, 1996, s.60). Bhanthumnavin (2003, s.79), yönetici desteğini; "yönetici ile çalışan arasındaki olumlu iş ilişkisi" olarak açıklamaktadır. Çünkü destekleyici yöneticiler, çalışanlarının ihtiyaçlarını karşılayarak onları daha iyi çalışmaları doğrultusunda teşvik ederler. Yoon ve Lim (1999), yönetici desteğini; "çalışanların bir üst amirleri tarafindan gördükleri destek" şeklinde değerlendirmektedir (Yoon ve Lim, 1999, s.925). Bu bakış açısından hareketle, bu çalışma kapsamında yönetici desteği düzeyi; çalışanların bir üst amirlerinin onlara verdikleri desteğe ilişkin algıları üzerinden belirlenmektedir.

Bhanthumnavin (2000) yönetici desteğini; "bilgisel", "maddi" ve "duygusal" anlamda üçe ayırmaktadır. Bilgisel anlamda yönetici desteği; çal1şanların verimliliğini arttırmak amacıyla yönetici tarafından uygulanan ödül, ceza, geri bildirim ve rehberlik etme yanında yöneticinin işe ilişkin bilgi ve becerilerini kapsamaktadır. Maddi anlamda yönetici desteği ise yöneticilerin çalışanlarına zaman ayırmalarını ve onlar için yaptıkları mal, teçhizat ve finansal yardımları içermektedir. Son olarak duygusal anlamda yönetici desteği; "yöneticilerin çalışanlarına değer vermesi, ilgi ve sevgi göstermesi, saygı duyması, çalışanlarının iş ortamında karşılaştıkları zorlukların (örn.: stres ve çatışma gibi) üstesinden gelebilmeleri için onlara gerekli yardımları yapması" şeklinde ifade edilebilir. Duygusal destek; hem sözlü hem de sözlü olmayan (örn.: el sıkışma, sarılma ve kucaklama gibi) biçimde olabilir (Bhanthumnavin, 2000, s.160).

Literatüdeki ampirik çalışmalarda, algılanan yönetici desteğinin; içsel motivasyonu (Khalid, Rathore ve Aslam, 2017), mutluluğu (Bardakoğlu, Akgündüz, Kızılcalığlu ve Yeşilyurt, 2017), iş tatminini (Qureshi ve Hamid, 2017), iş performansını (Azman, Sieng, Ajis, Dollah ve Boerhannoeddin, 2009), örgüte bağlılığı ve örgütsel vatandaşlık davranışlarını (Wang, 2014) arttırdığı, iş stresini (Taş ve Özkara, 2018; Wickramasinghe, 2012), 
tükenmişliği (Salahian, Oreizi, Abedi ve Soltani, 2012) ve işten ayrılma niyetini (Newman, Thanacoody ve Hui, 2012; Taş ve Özkara, 2018) ise azalttığ 1 istatistiksel olarak ispatlanmıştır.

\section{Lider-Üye Etkileşimi}

Literatürde; algılanan yönetici desteğine ilişkin farklı tanımlar bulunmaktadır. Yönetici desteği; "yöneticilerin, çalışanlarının örgüte yaptıkları katkılara değer vermesi ve onları önemsemesi düzeylerine dair çalışanların inançları" şeklinde tanımlanabilir (Pohl ve Galletta, 2016, s.62). Diğer bir tanıma göre, yönetici desteği; "yöneticilerin çalı̧̧anlarına destek olması, onlara ilgi göstermesi, onları amaçları başarmaları doğrultusunda cesaretlendirerek motive etmeleridir" (Babin ve Boles, 1996, s.60). Bhanthumnavin (2003, s.79), yönetici desteğini; "yönetici ile çalışan arasındaki olumlu iş ilişkisi" olarak açıklamaktadır. Çünkü destekleyici yöneticiler, çalışanlarının ihtiyaçlarını karşılayarak onları daha iyi çalışmaları doğrultusunda teşvik ederler. Yoon ve Lim (1999), yönetici desteğini; "çalışanların bir üst amirleri tarafından gördükleri destek" şeklinde değerlendirmektedir (Yoon ve Lim, 1999, s.925). Bu bakış açısından hareketle, bu çalışma kapsamında yönetici desteği düzeyi; çalışanların bir üst amirlerinin onlara verdikleri desteğe ilişkin algıları üzerinden belirlenmektedir.

Literatürdeki çoğu liderlik teorisi, liderden izleyicilerine doğru giden etki üzerine yoğunlaşmaktadır. Lider-üye etkileşimi teorisi ise lider ile izleyicileri arasındaki ilişkileri iki yönlü olarak inceler. Başka bir ifadeyle lider-üye etkileşimi teorisi, lider ve izleyicileri arasındaki ikili ilişkileri yani etkileşimi analiz eder (Gültekin, 2014, s.31). Lider-üye etkileşimi teorisi çerçevesinde, ikili ilişkiler çalışmanın kapsamına göre lider-üye etkileşimi ya da yönetici-ast etkileşimi ekseninde ele alınabilir (Özutku, Ağca ve Cevrioğlu, 2008). Lider (Yönetici)-üye (ast) etkileşiminin kalitesi; hem liderlerin (yöneticilerin) hem de izleyicilerin (astların) özelliklerine, tutum ve davranışlarına bağlıdır (Ergeneli, 2006, s.230; Gültekin, 2014, s.33). Ayrıca bu etkileşimin kalite düzeyi hem liderlerin (yöneticilerin) hem de izleycilerin (astların) algıları üzerinden hesaplanabilmektedir (Maslyn ve Uhl-Bien, 2001, s.703). Bu çalışma kapsamında ise yönetici-ast etkileşiminin kalite düzeyi astların algıları üzerinden belirlenmektedir. 
Lider-üye etkileşimi teorisi, Sosyal Değişim Kuramı ve Rol Kuramı (Role Theory-Kahn, Wolfe, Quinn, Snoek ve Rosenthal, 1965) üzerinden Graen ve arkadaşları tarafından 1970'lerde geliştirilmiştir (Aktaran Liden ve Marslyn, 1998, s.44). Rol Kuramı'na göre; örgütteki bir pozisyonu işgal eden çalışan, bu pozisyona bağlı olarak bazı davranış kalıplarını sergilemelidir (Kahn vd., 1965). Rol Kuramı'nda çalışanların sadece pozisyonlarına bağlı davranışları üzerinde durulur. Halbuki lider-üye etkileşimi teorisi açısından çalışanların davranışları açıklanırken çalışanların pozisyonlarından bağımısız bir biçimde tutumları, motivasyonları ve kişilik özellikleri de önem arz eder (Liden ve Marslyn, 1998). Sosyal Değişim Kuramı'na göre ise karşlıklılık ilkesi temelinde bireyler arasındaki olumlu ve faydalı eylemler taraflar arasında zorunluluk hissi yaratarak yüksek kalitede değiş-tokuş ilişkisinin oluşmasını sağlamakta ve böylece karşılıklı ilişkinin yani etkileşimin kalitesi artmaktadır (Blau, 1964; Settoon vd., 1996).

Lider-üye etkileşimi teorisine göre; lider (yönetici) her izleyicisine (astına) aynı biçimde davranmaz. Bu teoriye göre; üstler, güvendikleri küçük bir grup astla özel bir ilişki içindedir. İçerisinde yer alan bireylerin bazı ayrıcalıklara sahip olduğu bu grup, "iç grup" olarak tanımlanmakta ve iç grubun dişında yer alan astlar ise "dış grubu" oluşturmaktadır. Lider, diş grupta yer alan astlara fazla zaman ayırmamaktadır ve ilgi göstermemektedir (Ergeneli, 2006, s.229; Graen ve Scandura, 1987; Robbins ve Judge, 2013, s.386). İç grupta lider-üye etkileşiminin kalitesi diş gruba göre daha yüksektir (Liden, Sparrowe ve Wayne, 1997).

Literatürde; lider-üye etkileşiminin boyutlarına, öncüllerine ve sonuçlarına ilişkin tam bir görüş birliği bulunmamaktadır. Örneğin; güven, alanyazında lider-üye etkileşiminin hem bir alt boyutu hem de öncülü ve sonucu olarak değerlendirilebilmektedir. Bununla birlikte, lider-üye etkileşiminin kalitesindeki artışın; iş tatminini ve örgütsel bağlılığı yükselttiği, işten ayrılma niyetini ise azalttığı literatürde savunulmaktadır (Van Breukelen, Schyns ve Le Blanc, 2006, s.303-304). Literatürde; lider-üye etkileşimine ilişkin boyutlar hususunda farklı görüşler bulunmaktadır. Bu hususta gerçekleştirilen ilk çalışmalarda; lider-üye etkileşiminin kalitesi tek boyutta ele alırken, son dönemdeki çalışmalarda çok boyutlu bir yapıda incelenmektedir. Liden ve Maslyn (1998) lider-üye etkileşiminin kalitesini; "etki (affect)", "sadakat (loyalty)", "katk1 (contribution)" ve "mesleki 
sayg1 (professional respect)" olmak üzere dört boyuta ayırmaktadır. Bu sinıflandırmanın literatürde genel olarak kabul gördüğü ifade edilebilir (Davis ve Gardner, 2004, s.459; Gültekin, 2014, s.39). Bu çalışma kapsamında da Liden ve Maslyn (1998) tarafından yapılan çalışmadan hareketle lider-üye etkileşiminin kalitesi dört boyutta ele alınmaktadır. Bu boyutlar şu şekilde açılanabilmektedir (Liden ve Maslyn, 1998, s.50-65):

- Etki: Bu boyut; lider ve izleyicinin iş ya da mesleki değerlerden bağımsız olarak birbirlerine karşı hissettikleri duygusal yakınlık derecesidir. Etki boyutunun temelinde kişisel çekicilik yatmaktadır. Kişisel çekicilik beraberinde lider ve izleyicinin birbirlerine karşı besledikleri hoşlanma duygusunu getirmektedir.

- Sadakat: Lider ve izleyicinin birbirlerine ne derece sadık olduklarını ortaya koyan bu boyut; lider-üye etkileşiminin kalitesinin sağlanmasinda ve devam ettirilmesinde önemlidir. Bu boyut; bireylerin başkaları karşısında birbirlerinin özelliklerini ve davranışlarını desteklemelerini içermektedir.

- Katkı: Lider; izleyicinin performansını diğer izleyicilerin performansından daha iyi bulursa, bu izleyiciye diğer izleyicilere göre daha fazla örgütsel kaynak sunar. Böylece bu izleyicinin performansı daha da artmakta ve lider-üye etkileşiminin kalitesi de yükselmektedir.

- Mesleki Saygı: Bu boyut; lider ve izleyicinin yaptıkları iş bağlamında örgüt içinde ve dışında sahip oldukları üne ilişkin bir algıdır. Lider; uzmanlı gücüne sahiptir ve bu güç mesleki saygı açısından çok önemlidir. Mesleki saygıya; örgütteki her üye sahip olabilir. Bunun için örgüt üyesi hakkında diğer örgüt üyeleri tarafından örgüt içinde ve/veya dışında kendi çalışma alanında oldukça donanımlı olduğu algısının oluşması gerekmektedir. Bu algının oluşmasında; kişinin kazandığı ödüller ve mesleki anlamda takdir edilmesi, ayrıca örgüt içinden ve/veya dışından kişiler tarafından bu kişi hakkında olumlu yorumlar yapılması ve kişinin geçmişi etkili olabilir. Bu bağlamda; bu kişi ile birlikte çalışmadan, hatta onunla tanışmadan önce o kişiye ilişkin mesleki saygı algısı oluşabilir. 


\section{Algılanan Yönetici Desteği ile Lider-Üye Etkileşimi Arasındaki İlişki}

Lider (yönetici) ve üye (ast) arasında kurulan düşük kaliteli bir ilişkide; astlar üstlerinden daha düşük düzeyde destek gördüklerini, yüksek kaliteli bir ilişkide ise daha yüksek düzeyde destek gördüklerini düşünürler (Çalışkan, 2009). Chen, Wang, Chang ve Hu (2008) tarafından yapılan çalışmada; lider-üye etkileşiminin kalitesindeki artış algılanan yönetici desteği düzeyini yükseltirken, literatürdeki diğer çalışmalarda (Akkoç vd., 2013; Gkorezis, 2015; Karayel, 2016) ise algılanan yönetici desteği düzeyindeki artış lider-üye etkileşiminin kalitesini yükseltmektedir.

Çalışma kapsamında; teorik bilgiler ve ampirik çalışmalardaki genel eğilimden hareketle algılanan yönetici desteğinin lider-üye etkileşiminin kalitesini anlamlı ve pozitif bir şekilde etkilemesi beklenmektedir.

\section{Örgütsel Sinizm}

Felsefe ile bağlantılı olan sinizm olgusu; psikoloji, sosyoloji, yönetim ve siyaset bilimleri gibi farklı alanlarda teorik ve ampirik çalışmaların yapıldığı disiplinler arası bir konudur (Gültekin, 2014, s.19). Sinizmin temelinde; adalet, dürüstlük ve içtenlik gibi ilkelerin kişisel çıkarlara feda edilmesi yatmaktadır (James, 2005, s.1). Sinik (kinik) insanlar iyilik kavramına inanmazlar. Bütün insanların samimiyetsiz ve çıkarcı olduğunu düşünürler. Bu nedenle insanların sadece kendi çıarlarına hizmet etmesi gerektiğine inanırlar ve kendi çıkarlarını kurumun ve toplumun çıkarlarından üstün tutarlar (Andersson ve Bateman, 1997, s.450; De-Bakker, 2006, s.123; İnce, 2018, s.509). Literatürde, sinizmin; örgütsel sinizm, çalışan sinizmi, iş sinizmi (mesleki sinizm), kişilik sinizmi ve toplumsal sinizm gibi türleri bulunmaktadır (Dean, Brandes ve Dharwadkar, 1998). Bu çalışma kapsamında ise örgütsel sinizme odaklanılmaktadır.

Kişilik sinizmi araştırmacıları; sinizmi, doğuştan gelen bir kişilik özelliği olarak kabul etmektedirler (Eaton, 2000, s.7). Örgütsel sinizm araştırmacıları ise sinizmin sadece bir kişilik özelliği olmadığını savunurlar. Çünkü örgütün politika ve uygulamalarının çalışanlar tarafından nasıl algılandığ1 da örgütsel sinizm üzerinde etkilidir (FitzGerald, 2002, s.8). Örgütsel sinizm; örgütün dürüstlükten (bütünlükten) yoksun olduğuna dair çalışanların inancı nedeniyle bu çalışanların örgütüne karşı geliştirdiği 
olumsuz duygu, tutum ve davranışları ifade etmektedir (Dean vd., 1998, s.345). Çalışan sinizmi ve örgütsel sinizm birbirlerine çok yakın içe içe kavramlar olmakla birlikte farklı kavramlardır. Çalışan sinizminin temelinde çalışan ile işveren arasındaki psikolojik sözleşme ihlallerine dair çalışanların algısı yatmaktadır. Bu noktada; çalışanların kişilik özelliklerinin belirleyici olduğu söylenebilir. Buna karşın; örgütsel sinizmde kişilik özelliklerinden ziyade örgütsel faktörler öne çıkmaktadır (Dean vd., 1998, s. 344; Gültekin, 2014, s.21-22).

Örgütsel sinizm boyutları; bilişsel (cognitive/belief-based), duyuşsal (affective/affect-based) ve davranışsal (behavioral) sinizm olmak üzere üçe ayrılabilmektedir. Bu boyutlar şu şekilde açıklanabilir (Brandes, Dharwadkar ve Dean, 1999; Dean vd., 1998, s.345-346):

- Bilişsel sinizm: Bu boyutun temelinde örgütlerin dürüstlükten yoksun olduğu inancı yatmaktadır. Çalışanlar; örgütlerini ciddiye almazlar. Çünkü örgütteki uygulamaların örgütsel ilkelerden yoksun ve tutarsız olduğunu düşünürler.

- Duyuşsal sinizm: Bu boyut; sinirlenmeye, çileden çıkmaya, gerilmeye ve endişe duymaya yol açan çeşitli kuvvetli duyguların birleşiminden oluşur.

- Davranışsal sinizm: Bu boyut; çalışanların örgütleri hakkında hem sözlü biçimde dalga geçmelerini ve küçümseyici ifadeler kullanmalarını hem de sözsüz biçimde birbirleriyle imalı bakışmalarını ve manalı gülümsemelerini kapsamaktadır.

İnce (2018) çalışmasında; yaş, cinsiyet, medeni hal, mesleki kıdem, gelir düzeyi, eğitim durumu ve deneyimler gibi bireysel faktörler yanında yıldırma, stres, çatışma, adaletsizlik, değişim, desteksizlik, iletişimsizlik ve küçülme gibi örgütsel faktörleri de örgütsel sinizmin nedenleri arasında göstermektedir (İnce, 2018, s.511). James (2005) tarafından yapılan çalışmada, örgütsel sinizmin; üretkenlik karşıtı iş davranışlarına sebep olduğu istatistiksel olarak ispatlanmıştır (James, 2005). Johnson ve O'Leary-Kelly (2003) tarafından gerçekleştirilen çalışmada; örgütsel sinizmin iş tatminini ve örgütsel bağlılığ miştir (Johnson ve O'Leary-Kelly, 2003). Örgütsel sinizmin, örgüt üzerindeki olumsuz etkileri dikkate alındığında, örgütsel sinizm ile mücadele yöntemleri önem kazanmaktadır. İnce (2018, s.512-515) bu yöntemleri "örgüt içi etkili iletişimin sağlanması", "çalışanların güvenini kazanmak", 
"çalışanlarını tanıyan etkili bir lider olmak", "çalışanların gelişimine katkıda bulunmak", "sinik yapıdan arınmış kriz takımları oluşturmak", "aşırı merkezileşmeden kaçınmak" ve "esnek örgüt yapısı oluşturmak" başlıkları altında toparlamaktadır.

\section{Algılanan Yönetici Desteği ile Örgütsel Sinizm Arasındaki İlişki}

Algılanan yönetici desteği; Cole, Brunch ve Vogel (2006) tarafından Almanya'da yapılan çalışmada çalışan sinizmiyle, Neves (2012) tarafından Portekiz'de gerçekleştirilen çalışmada ise örgütsel sinizmle anlamlı ve negatif ilişkilere sahiptir. Ece, Kurban ve Gültekin (2018) Düzce İli kamu kurumu çalışanları üzerinde yaptıkları araştırmada; algılanan yönetici desteği düzeyindeki artışın örgütsel sinizm düzeyini azalttığını tespit etmişlerdir.

Bu bilgiler ışığında, çalışma kapsamında; algılanan yönetici desteğinin örgütsel sinizmi anlamlı ve negatif bir şekilde etkilemesi beklenmektedir.

\section{Lider-Üye Etkileşimi ile Örgütsel Sinizm Arasındaki İlişki}

Gkorezis (2015) Yunanistan'daki kamu çalışanları üzerinde, Gültekin (2014) ise Türkiye' deki devlet üniversitelerinde görev yapan akademik ve idari personel üzerinde gerçekleştirdikleri araştırmalarda; lider-üye etkileşiminin kalitesindeki artışı örgütsel sinizmi azaltığını tespit etmişlerdir.

Bu bilgiler ışığında, çalışma kapsamında; lider-üye etkileşimi kalitesinin örgütsel sinizmi anlamlı ve negatif bir şekilde etkilemesi beklenmektedir.

\section{Algılanan Yönetici Desteği ile Örgütsel Sinizm Arasındaki İlişkide Li- der-Üye Etkileşiminin Aracılık Etkisi}

Literatür taramasında algılanan yönetici desteği ile örgütsel sinizmin arasındaki ilişkide lider-üye etkileşiminin aracılık rolünün incelendiği bir çalışmaya rastlanılmamıştır. Fakat literatürde benzer mekanizmaların kurulduğu çalışmalar yer almaktadır. Örn.: Cole vd. (2006) tarafından Almanya' da gerçekleştirilen çalışmada; algılanan yönetici desteği ile çalışan 
sinizmi arasındaki ilişkide çalışanların olumlu ve olumsuz duygularının tam aracı değişken olduğu tespit edilmiştir. Ayrıca Gkorezis (2015) tarafından Yunanistan'da yapılan araştırmada; algılanan yönetici desteği ile çalışanların çevre yanlısı davranışı (pro-environmental behavior) arasındaki ilişkide lider-üye etkileşiminin kısmi aracı değişken olduğunu istatistiksel olarak ispatlamaktadır. Buna karşın algılanan yönetici desteği ile çalışanların iş performansı arasındaki ilişkide lider-üye etkileşiminin sahip olduğu role ilişkin literatürdeki çalışmalarda çelişkili sonuçlar bulunmaktadır. Karayel'in (2016) belediye çalışanları üzerinde yaptığı araştırmanın sonuçlarına göre bu ilişkide lider-üye etkileşimi aracı değişken değildir. Akkoç vd. (2013) tarafından savunma sanayii çalışanları üzerinde gerçekleştirilen çalışmada ise bu ilişkide lider-üye etkileşimi kısmi aracı değişken olarak belirlenmiştir.

\section{Yöntem}

Bu çalışmanın yöntem bölümünde; araştıma modeline, hipotezine, örnekleme, veri toplama araçlarına, çalışmada kullanılan istatistiklerin hangi programlarda hangi sırada yapıldığına yani işleme yer verilmektedir.

\section{Araştırma Modeli ve Hipotezi}

Çalışmanın buraya kadarki kısmında açıklanan teorik bilgiler ve ampirik çalışmalardan hareketle Şekil 1'de görüldüğü üzere çalışmanın araştırma modeli kurulmuş ve hipotezi geliştirilmiştir.

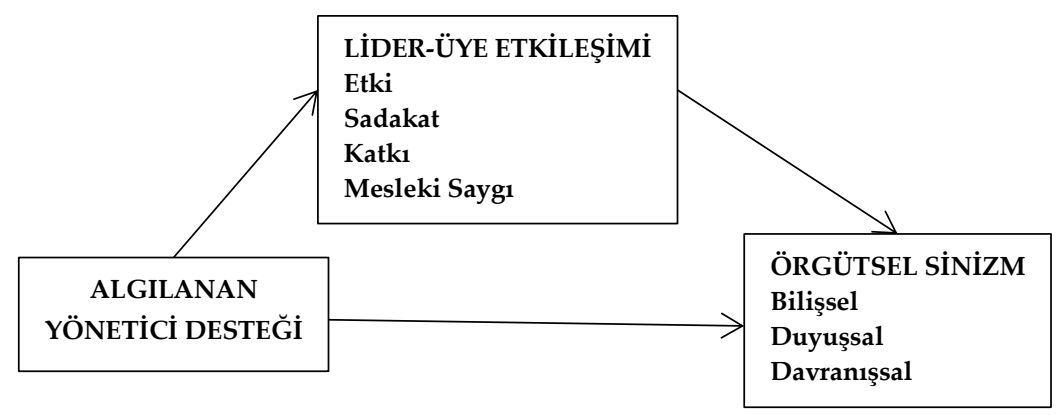

Şekil 1. Çalışmanın araştırma modeli. 
Hipotez: Algılanan yönetici desteği ile örgütsel sinizm arasındaki ilişkide lider-üye etkileşiminin aracılık etkisi vardır.

\section{Örneklem ve Veri Toplama Araçları}

Araştırmanın evreni; Ankara'daki bir kamu kurumunun merkez teşkilatında çalışan mühendisleri kapsamaktadır. Örneklem seçilmeyerek, bu kurumda çalışan mühendislerin tamamı evren kabul edilmiş ve bu evrenin tamamını oluşturan toplam 401 mühendise ulaşılması hedeflenmiştir. Veri toplama yöntemi olarak anket yöntemi kullanılmıştır. Anketler 2018 yılı ekim-kasım ayları içerisinde yaklaşık 1 aylık bir sürede kapalı zarf usulü kullanılarak toplanmıştır. Evrenin tamamını oluşturan 401 mühendisten 299 'u tamamen ya da kısmen anket formunu doldurmuştur. Geri dönüş oranı yaklaşık \%75'tir. Bu oranın tatmin edici bir düzeyde olduğu söylenebilir. Ancak çıplak gözle yapılan ön incelemelerin sonucunda elde edilen bu anketlerin sadece 215'inin düzgün bir şekilde doldurulduğu ve araştırmada kullanılabilir nitelikte olduğu tespit edilmiştir. Araştırmanın veri seti büyüklüğü "veri setinin kontrolü ve analize hazırlanması" süreci sonunda kesinleşmektedir.

Anket formu dört bölümden oluşmaktadır. Birinci bölümde algılanan yönetici desteğini ölçmek için Giray ve Şahin (2012) tarafından geliştirilen 11 maddelik ölçek; ikinci bölümde lider-üye etkileşiminin kalitesini ölçmek için Liden ve Maslyn (1998) tarafından geliştirilen 3 maddelik etki, 3 maddelik sadakat, 3 maddelik katkı ve 3 maddelik mesleki saygı olmak üzere dört boyuttan oluşan 12 maddelik ölçek; üçüncü bölümde örgüte ilişkin sinik tutumu belirlemek için Brandes vd. (1999) tarafından geliştirilen 5 maddelik bilişsel, 4 maddelik duyuşsal ve 4 maddelik davranışsal olmak üzere üç boyuttan oluşan 13 maddelik ölçek kullanılmıştır. Bu ölçeklerin puanlaması 5'li Likert tipi ölçme düzeyinde (1=Kesinlikle Katılmiyorum, 2=Kısmen Katılmıyorum, 3=Orta Düzeyde Katılıyorum, 4=Kısmen Katılıyorum, 5=Tamamen Katılıyorum) derecelendirilmiştir. Son olarak, dördüncü bölümde ise katılımclardan cinsiyet, yaş, eğitim düzeyi ve kurumda çalışma süresi gibi bazı demografik sorulara yanıt vermeleri istenmiştir. 


\section{İşlem}

Nicel bir araştırmanın gerçekleştirildiği bu çalışmada; anket yöntemiyle veri toplanmıştır. İlk olarak, "SPSS 24" programı kullanılarak veri girişi yapılmıştır. Veri setinin kontrolü ve analize hazırlanması (ön analizleri) tamamlandıktan sonra, araştırmaya katılanların demografik özellikleri belirlenmiştir. Daha sonra "AMOS 24" programı kullanılarak araştırma modelinin yapı geçerliliği doğrulayıcı faktör analizi-DFA (confirmatory factor analysis-CFA) ile sınanmıştır. Akabinde, "SPSS 24" programı kullanılarak araştırma modelindeki değişkenlerin ortalama ve standart sapma değerleri hesaplanmış, güvenilirlik ve Pearson korelasyon analizleri yapılmıştır. Araştırma hipotezi "AMOS 24" programı kullanılarak yapısal eşitlik modellemesi-YEM (structural equation modeling-SEM) ile test edildikten sonra, son olarak interaktif ortamda Sobel testi ile analiz edilmiştir.

\section{Bulgular}

Bu çalışmanın bulgular bölümünde; ön analizlere, katılımcılara ilişkin betimsel bulgulara, geçerlilik / güvenilirlik / korelasyon analizlerine ve araştırma hipotezinin test edilmesine yer verilmektedir.

\section{Ön Analizler}

$\mathrm{Bu}$ çalışma kapsamında; veri setinin kontrolü ve analize hazırlanması amacıyla Tabachnick ve Fidell (2013) tarafından önerilen yöntem kullanılmıştır. Bu yöntemde; veri setinin doğruluğu, eksik veri analizi, normallik testi ve çoklu bağlantı analizi olmak üzere dört aşama yer almaktadır. Yapılan inceleme sonucunda tüm ölçek maddelerine ait basıklık ve çarpıklık değerlerinin -1.5 ile +1.5 değerleri arasında değiştiği tespit edilmiş ve böylece verinin normal dağılım özelliğine sahip olduğu kabul edilmiştir. Ön analizler sonucunda hiçbir katılımcı analizden çıkarılmamıştır. Böylece araştırmanın veri seti büyüklüğü 215 olarak kesinleşmiştir. Araştırmanın evreninin yaklaşık \%54'üne ulaşılmıştır. Ulaşılan bu oran dikkate alınarak veri seti büyüklüğünün çalışma kapsamında yeterli olduğu düşünülmüştür ve ayrıca veri setinin evreni temsil eder nitelikte olduğu varsayılmıştır. 


\section{Katılımcılara İlişkin Betimsel Bulgular}

Araştırmaya katılan çalışanların cinsiyet, yaş, eğitim düzeyi, çalıştıkları sektör ve kurumda çalışma süreleri gibi demografik özellikleri sıklık ve yüzde bazında Tablo 1'de görülmektedir.

Tablo 1. Araştırmaya katılanların demografik özellikleri

\begin{tabular}{lll}
\hline Demografik Özellikler & Siklık (n) & Yüzde(\%) \\
\hline Cinsiyet & & 20.0 \\
\hline Kadın & 43 & 80.0 \\
\hline Erkek & 172 & \\
\hline Yaş & & 4.2 \\
\hline $18-28$ yaş & 9 & 25.1 \\
\hline $29-38$ yaş & 54 & 28.9 \\
\hline 39-48 yaş & 62 & 26.0 \\
\hline $49-58$ yaş & 56 & 15.8 \\
\hline 59 yaş ve üzeri & 34 & 76.3 \\
\hline Eğitim Düzeyi & & 19.1 \\
\hline Lisans & 164 & 4.6 \\
\hline Yüksek Lisans & 41 & \\
\hline Doktora & 10 & 0.0 \\
\hline Kurumda Çalışma Süresi & & 3.7 \\
\hline 1 y1ldan az & 0 & 5.1 \\
\hline $1-5$ y1l & 8 & 20.0 \\
\hline $6-10$ y1l & 11 & 22.3 \\
\hline $11-15$ yıl & 43 & 22.8 \\
\hline $16-20$ y1l & 48 & 26.1 \\
\hline $21-25$ y1l & 49 & \\
\hline 26 y1l ve üzeri & 56 & \\
\hline
\end{tabular}

Tablo 1'de de görüldüğü üzere araştırmaya katılan çalışanların \%20.0'si kadın, \%80.0'i erkektir. Kurumda çalışan kadın mühendis sayısı erkeklere göre çok daha azdır. Bu durum; araştırmanın veri setinde de kendini göstermektedir. Katılımcıların \%4.2'si 18-28 yaş, \%25.1'i 29-38 yaş, \%28.9'u 39-48 yaş, \%26'sı 49-58 yaş aralığında, \%15.8'i ise 59 yaş ve üzerindedir. Katılımcıların küçük bir kısmı 18-28 yaş aralığındadır. 29-38 yaş, 38-48 yaş ve 49-58 yaş aralıkları ise 59 yaş ve üzerindeki katılımcıların sıklığından daha fazladır ve kendi aralarında dengeli bir dağılım göstermektedirler. Katılımcıların eğitim düzeyleri incelendiğinde \%76.3'ünün lisans, 
\%19.1'inin yüksek lisans ve \%4.6'sının doktora mezunu olduğu görülmektedir. Katılımcıların çoğunluğu lisans mezunlarından oluşmaktadır. Bununla birlikte Türkiye geneli düşünüldüğünde özellikle yüksek lisans mezunlarının katılımcılar içerisinde azımsanmayacak bir sıklık ve yüzdeye sahip olduğu söylenebilir. Katılımcıların kurumda çalışma süreleri incelendiğinde ise \%0.0'ının 1 yıldan az bir süredir, \%3.7'sinin 1-5 yıl, \%5.1'inin 6-10 yıl, \%20.0'sinin 11-15 yıl, \%22.3'ünün 16-20 y1l, \%22.8'inin 21-25 yıl arasında, \%26.1'inin 26 yıl ve üzerinde kurumda görev yaptıkları belirlenmiştir. Ayrıca 1-10 yıl aralığında kurumda görev yapaların sayısı oldukça düşüktür. Diğer yaş aralıkları ise görece daha yüksek sıklık ve yüzdeye sahiptir. Aynı zamanda kendi aralarında dengeli bir dağılım göstermektedirler. Katılımcıların sadece \%4.2'sinin 18-28 yaş aralığında olması ve 1 yıldan az süredir kurumda çalışan sayısının " 0 " olması, bu kuruma özellikle son yıllarda devlet tarafından çok az sayıda mühendis alındiğına işaret etmektedir.

\section{Geçerlilik Analizi}

Anderson ve Gerbing (1988) tarafından öne sürülen iki aşamalı yaklaşıma göre; araştırmanın hipotezini incelemek amacıyla çalışmanın araştırma modeli yapısal eşitlik modellemesi ile test edilmeden önce, ilk olarak modelin yapı geçerliliği araştırılmalıdır (Anderson ve Gerbing, 1988). "AMOS 24" programı kullanılarak çalışmanın araştırma modeline bütün bir yapıda doğrulayıc faktör analizi (overall confimatory factor analysis) yapılmıştır. 3 değişken ve 36 maddeden oluşan ölçüm modeli en yüksek olabilirlik (maximum likelihood) yöntemi kullanılarak test edilmiştir. Doğrulayıcı faktör analizinde; Hair, Black, Babin ve Anderson (2010) tarafından önerilen prosedür uygulanarak faktör yükleri, standart hata kovaryans değerleri ve modifikasyon indeksleri incelenmiştir.

Gerçekleştirilen doğrulayıcı faktör analizi sonucuna göre; modeldeki tüm maddedeler anlamlıdır. Ayrıca Şekil 2'de de görüldügü üzere standardize edilmiş yol katsayıları (standardize edilmiş $\beta$ katsayısı; faktör yükü) algılanan yönetici desteği ölçeğinin maddeleri için .75-.88; lider-üye etkileşimi ölçeğinin alt boyutları için .95-1.03, etki boyutunun maddeleri için .59-.89, sadakat boyutunun maddeleri için .76-.85, katkı boyutunun 
maddeleri için .72-.87, mesleki sayg1 boyutunun maddeleri için .75-.87; örgütsel sinizm ölçeğinin alt boyutları için .76-.82, bilişsel boyutunun maddeleri için .64-.82, duyuşsal boyutunun maddeleri için .80-.95, davranışsal boyutunun maddeleri için .71-.78 arasında değişmektedir. Faktör yükleri incelendiğinde; tüm faktör yükü değerlerinin, Hair vd. (2010) tarafından önerilen minimum faktör yükü değeriden yani .40'dan yüksek olduğu görülmektedir. Bu nedenle faktör yüklerinin tamamı yeterli düzeydedir.

Tablo 2. Doğrulayıcı faktör analizi sonucunda ölçüm modeline ilişkin belirlenen uyum indeks değerleri

\begin{tabular}{llllll}
\hline Uyum İndeksleri & $\Delta \mathbf{X}^{2} / \mathbf{s d}$ & CFI & TLI & RMSEA & $\begin{array}{l}\text { HOEL- } \\
\text { TER.05 }\end{array}$ \\
\hline Eşik Değerler & $<5.0^{*}$ & $\geq 0.90^{* *}$ & $\geq 0.90^{* * *}$ & $<0.10^{* * * *}$ & $>75^{* * * * *}$ \\
Modelin Değerleri & 1.883 & 0.927 & 0.921 & 0.064 & 125 \\
\hline
\end{tabular}

Not:*Bentler ve Bonett (1980); **Hu ve Bentler (1999); ***Meydan ve Şeşen (2011); ***Browne ve Cudeck (1993); *****Emhan, Kula ve Töngür (2013)

Tablo 2'de de görüldüğg̈ü üzere çalışmanın ölçüm modeline ilişkin hesaplanan tüm uyum indeks değerleri yeterli düzeydedir $\left[\Delta \mathrm{X}^{2} / \mathrm{sd}=1.883\right.$, CFI=.927, TLI=.921, RMSEA=.064, HOELTER.05=125]. Böylece çalışmanın araştırma modelindeki hiçbir ölçek maddesinin hata terimi başka bir ölçek maddesinin hata terimiyle birleştirilmeden ve herhangi bir ölçek maddesi analiz dışında bırakılmadan araştırma modelinin yapı geçerliliği sağlanmiştır.

Bu çalışma çerçevesinde; araştırma modeline bütün bir yapıda doğrulayıcı faktör analizi yapılarak hem çalışmada kullanılan ölçeklerin geçerliliği sağlanmıştır hem de yapısal eşitlik modellemesi ile araştırma hipotezlerinin test edilebilmesi için gerekli zemin hazırlanmıştır. 


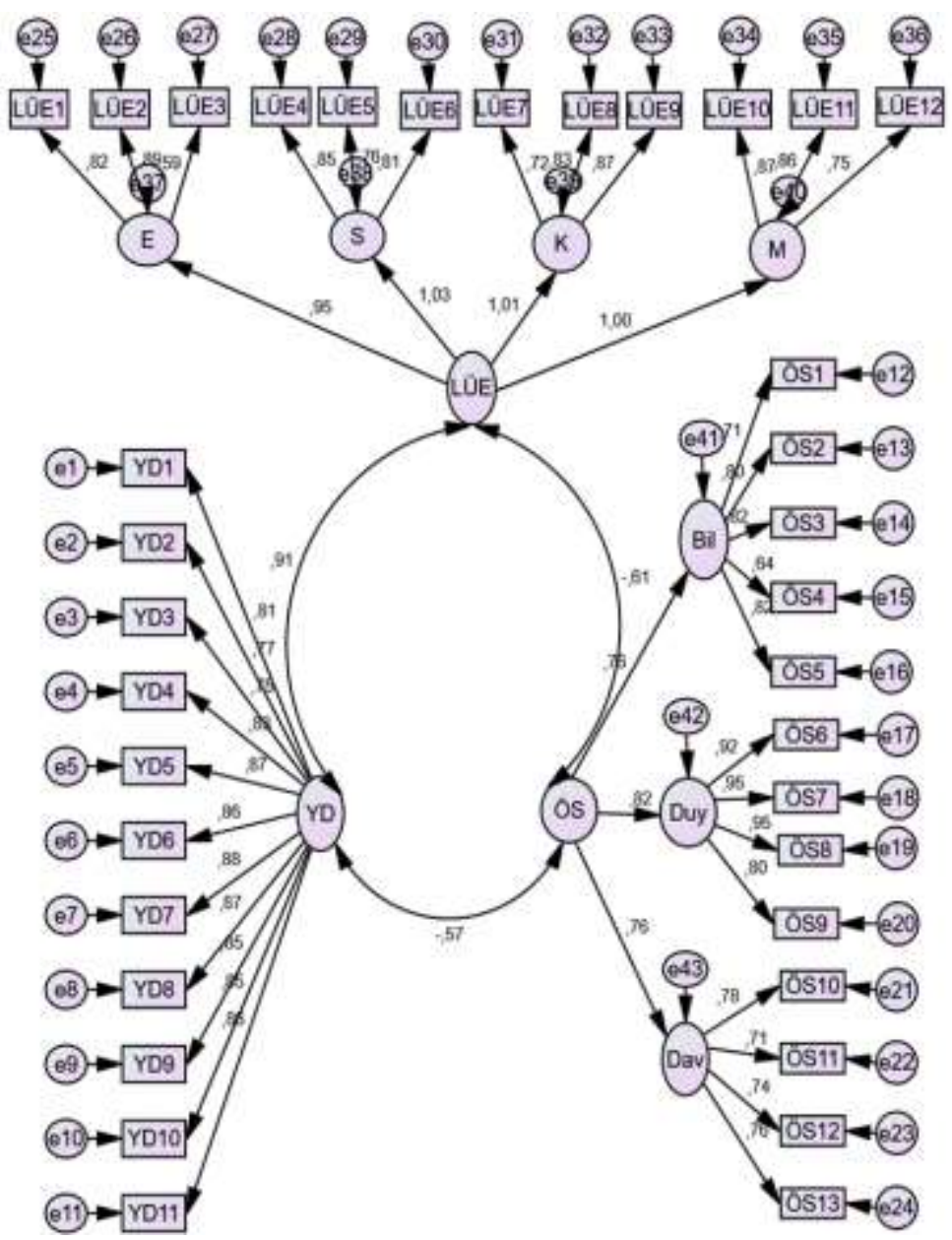

Şekil 2. Tüm değişkenleri kapsayan doğrulayıcı faktör analizi (DFA)²

\section{Güvenilirlik ve Korelasyon Analizleri}

Çalışmada yer alan değişkenlerin ortalama ve standart sapma değerleri, Pearson korelasyon ve güvenilirlik katsayıları Tablo 3'te görülmektedir.

\footnotetext{
2 Şekilde okların üzerinde gösterilen değerler noktadan sonraki rakamların iki basamağa yuvarlandığı standardize edilmiş regresyon katsayılarıdır. Kısaltmalar: YD: Algılanan Yönetici Desteği; LÜE: Lider-Üye Etkileşimi; E: Etki; S: Sadakat; K: Katkı; M: Mesleki Saygı; ÖS: Örgütsel Sinizm; Bil: Bilişsel; Duy: Duyuşsal; Dav: Davranışsal.
} 
Tablo 3'te de görüldüğü üzere araştırma kapsamında ele alınan değişkenlere ait en küçük güvenilirlik katsayısı değeri; ".80" olarak hesaplanmıştır. Bu değerin Hair vd. (2010) tarafından önerilen değerden yani “.70" den büyük olması araştırma kapsamında kullanılan tüm ölçeklerin güvenilir olduğunu göstermektedir.

Tablo 3. Araştırma değişkenlerine ait ortalama ve standart sapma değerleri, korelasyon ve güvenilirlik katsayıları

\begin{tabular}{|c|c|c|c|c|c|c|c|c|c|c|c|}
\hline Değişkenler & 1 & 2 & 3 & 4 & 5 & 6 & 7 & 8 & 9 & 10 & 11 \\
\hline 1.Cinsiyet & 1.00 & & & & & & & & & & \\
\hline $\begin{array}{l}\text { 2.Algilanan } \\
\text { Yönetici Desteği }\end{array}$ & .00 & $(.96)$ & & & & & & & & & \\
\hline $\begin{array}{l}\text { 3.Lider-üye } \\
\text { Etkileşimi } \\
\end{array}$ & -.01 & $.87^{* *}$ & $(.95)$ & & & & & & & & \\
\hline 4.Etki & -.05 & $.80^{* *}$ & $.90^{* *}$ & $(.80)$ & & & & & & & \\
\hline 5.Sadakat & .02 & $.84^{* *}$ & $.94^{* *}$ & $.80^{* *}$ & $(.85)$ & & & & & & \\
\hline 6.Katk1 & -.00 & $.81^{* *}$ & $.95^{* *}$ & $.81^{* *}$ & $.87^{* *}$ & $(.84)$ & & & & & \\
\hline $\begin{array}{l}\text { 7.Mesleki } \\
\text { Sayg1 } \\
\end{array}$ & -.02 & $.81^{* *}$ & $.94^{* *}$ & $.80^{* *}$ & $.87^{* *}$ & $.87^{* *}$ & $(.86)$ & & & & \\
\hline $\begin{array}{l}\text { 8.Örgütsel } \\
\text { Sinizm }\end{array}$ & -.01 & $-.49^{* *}$ & $-.52^{* *}$ & $-.47^{* *}$ & $-.49^{* *}$ & $-.52^{* *}$ & $-.46^{* *}$ & $(.92)$ & & & \\
\hline 9.Bilişsel & -.01 & $-.35^{* *}$ & $-.37^{* *}$ & $-.31^{* *}$ & $-.38^{* *}$ & $-.38^{* *}$ & $-.31^{* *}$ & $.84^{* *}$ & $(.87)$ & & \\
\hline 10.Duyuşsal & .11 & $-.50^{* *}$ & $-.51^{* *}$ & $-.47^{* *}$ & $-.47^{* *}$ & $-.50^{* *}$ & $-.48^{* *}$ & $.85^{* *}$ & $.57^{* *}$ & $(.94)$ & \\
\hline 11.Davranışsal & $-.15^{*}$ & $-.37^{* *}$ & $-.42^{* *}$ & $-.41^{* *}$ & $-.38^{* *}$ & $-.42^{* *}$ & $-.37^{* *}$ & $.80^{* *}$ & $.51^{* *}$ & $.56^{* *}$ & $(.83)$ \\
\hline Ortalama (M) & - & 3.42 & 3.34 & 3.46 & 3.20 & 3.43 & 3.28 & 2.63 & 2.98 & 2.40 & 2.42 \\
\hline Standart Sapma & & 1.04 & 1.02 & 1.02 & 1.12 & 1.07 & 1.12 & 0.89 & 0.99 & 1.22 & 1.01 \\
\hline
\end{tabular}

Yapılan korelasyon analizi sonucunda; demografik değişkenlerden cinsiyet ile algılanan yönetici desteği, lider-üye etkileşimi ve örgütsel sinizm arasında anlamlı ilişkiler tespit edilmemiştir. Buna karşın algılanan yönetici desteği ile lider-üye etkileşiminin kalitesi arasında pozitif yönlü ve anlamlı $(\mathrm{r}=0.87, \mathrm{p}<.01)$, algilanan yönetici desteği ile örgütsel sinizm arasında negatif yönlü ve anlamlı $(\mathrm{r}=-0.49, \mathrm{p}<.01)$, lider-üye etkileşiminin kalitesi ile örgütsel sinizm arasında negatif yönlü ve anlamlı $(\mathrm{r}=-0.52$, p<.01) ilişkiler olduğu tespit edilmiştir. Büyüköztürk (2012) bağımsız değişken ile aracı değişken arasında .80 üzerindeki korelasyonun çoklu bağlantı (multicollinearity) sorununa, .90 üzerindeki korelasyonun ise ciddi bir çoklu bağlantı sorununa işaret edebileceğini belirtmiştir. Bu kap- 
samda; algılanan yönetici desteği ile lider-üye etkileşimi değişkenleri arasında çoklu bağlantı ve otokorelasyon sorunu olup olmadığı incelenmiştir. Tespit edilen varyans oranları (tolerans değeri $>0.2$, VIF değeri $<10$ ) ve durum indeksi (CI değeri<30) değerleri çoklu bağlantı sorunu olmadığını, Durbin Watson $(1.5<\mathrm{DW}<2.5)$ değeri $(K a l a y c 1,2010)$ ise otokorelasyon olmadığını ortaya koymaktadır.

\section{Araştırma Hipotezinin Test Edilmesi}

Geçerlilik, güvenilirlik ve korelasyon analizlerinden sonra araştırma hipotezinin test edilmesine geçilmiştir. Çalışmanın araştırma hipotezinde; lider-üye etkileşiminin algılanan yönetici desteği ile örgütsel sinizm arasında aracı rol üstlendiği iddia edilmektedir. Literarüdeki bazı çalışmalarda (Hu ve Bentler, 1995; Kline, 2005) yapısal eşitlik modellemesinin verimli bir şekilde işlevini yerine getirebilmesi için gerekli olan en küçük örneklem büyüklüğünün 200 olduğu ifade edilmektedir. O halde; bu çalışma kapsamında geliştirilen araştırma hipotezi, araştırmanın veri seti büyüklüğü ( $n=215)$ dikkate alındığında yapısal eşitlik modellemesi ile test edilmeye uygundur. Çalışmanın araştırma hipotezi; "AMOS" programında en yüksek olabilirlik yöntemi kullanılarak yapısal eşitlik modellemesi ve Sobel testi ile sınanmıştır. Bu çalışmada; aracılı̆̆ın araştırılması amacıyla Meydan ve Şeşen (2011) tarafından önerilen yol izlenmiştir. Bu yol; Baron ve Kenny (1986) tarafından klasik regresyon analizi yapılırken kullanılan yöntemi temel almaktadır. Bu çerçevede; aracılığa ilişkin dört koşuldan ilkinin incelemesi için aracı değişkenin bulunmadığı yani sadece bağımsız değişkenin ve bağımlı değişkenin yer aldığ1 Şekil 3’te görülen model kurulmuştur.

Tablo 2' deki eşik değerler ile birinci modele ilişkin hesaplanan değerler $\left[\Delta \mathrm{X}^{2} / \mathrm{sd}=1.894, \mathrm{CFI}=.949\right.$, TLI=.943, RMSEA=.065, HOELTER.05=131] karşılaştırıldığında, tüm uyum indeks değerlerinin yeterli düzeyde olduğu görülmektedir. Söz konusu uyum indeks değerleri dikkate alınarak birinci modeldeki hiçbir ölçek maddesinin hata terimi başka bir ölçek maddesinin hata terimiyle birleştirilmeden ve herhangi bir ölçek maddesi analiz dışında bırakılmadan çalışmaya devam edilmesine karar verilmiştir. Birinci yapısal eşitlik modellemesi sonucuna göre; algılanan yönetici desteği 
örgütsel sinizmi negatif ve anlamlı bir şekilde etkilemektedir $(\beta=-0.572$; p<0.01). O halde; aracılığa ilişkin birinci koşul sağlanmıştır.

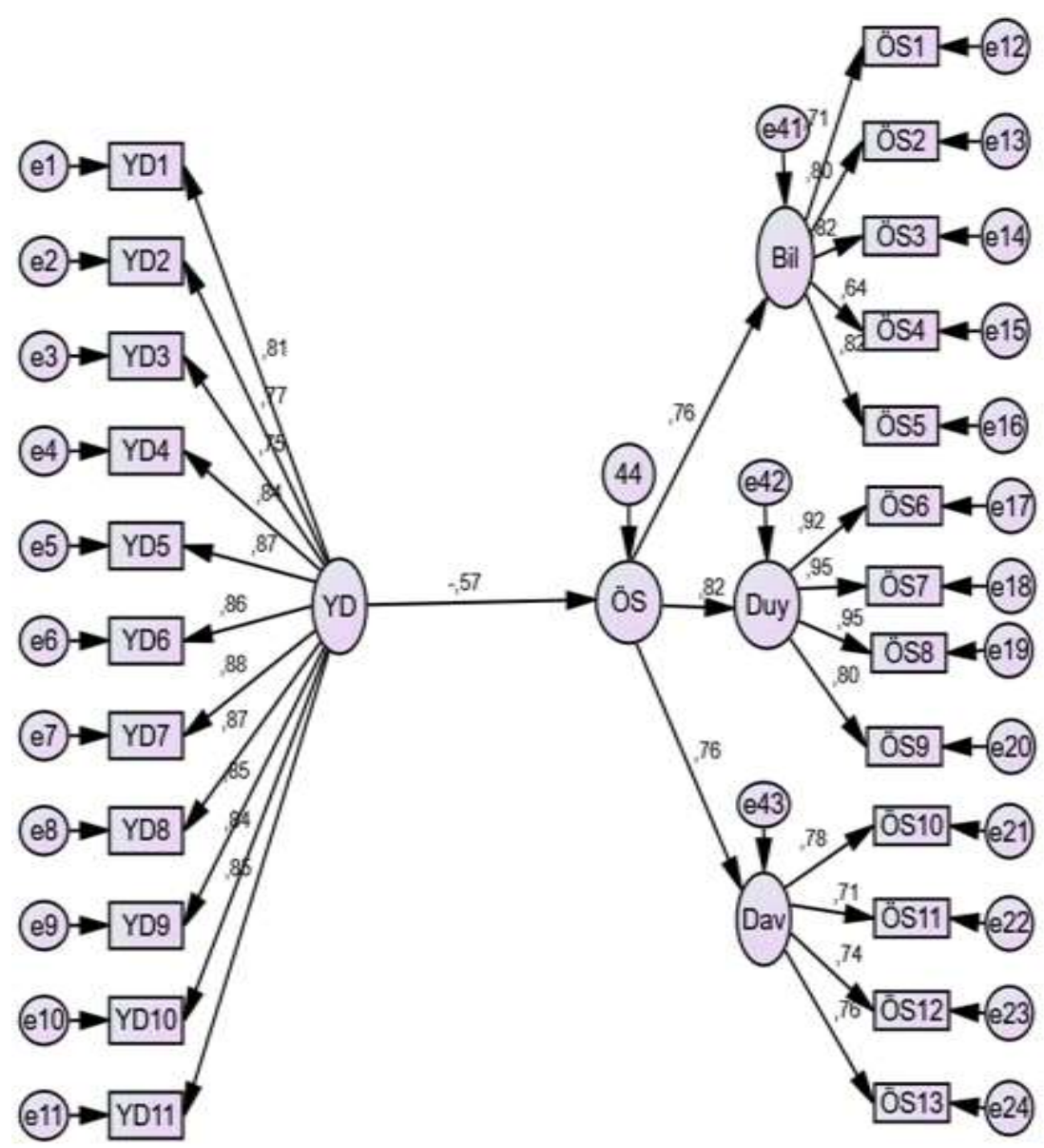

Şekil 3.Birinci yapısal eşitlik modellemesi ${ }^{3}$

Aracılığa ilişkin birinci koşul sağlandıktan sonra ikinci, üçüncü ve dördüncü koşulların da incelenmesi amacıyla ilk modele aracı değişken

\footnotetext{
${ }^{3}$ Notlar: Şekilde okların üzerinde gösterilen değerler noktadan sonraki rakamların iki basamağa yuvarlandığı standardize edilmiş regresyon katsayılarıdır. Kısaltmalar: YD: Algılanan Yönetici Desteği; ÖS: Örgütsel Sinizm; Bil :Bilişsel; Duy: Duyuşsal; Dav: Davranışsal.
} 
eklenerek çalışmanın araştırma modeli niteliğinde olan ve Şekil 4'te görülen ikinci bir model kurulmuştur.

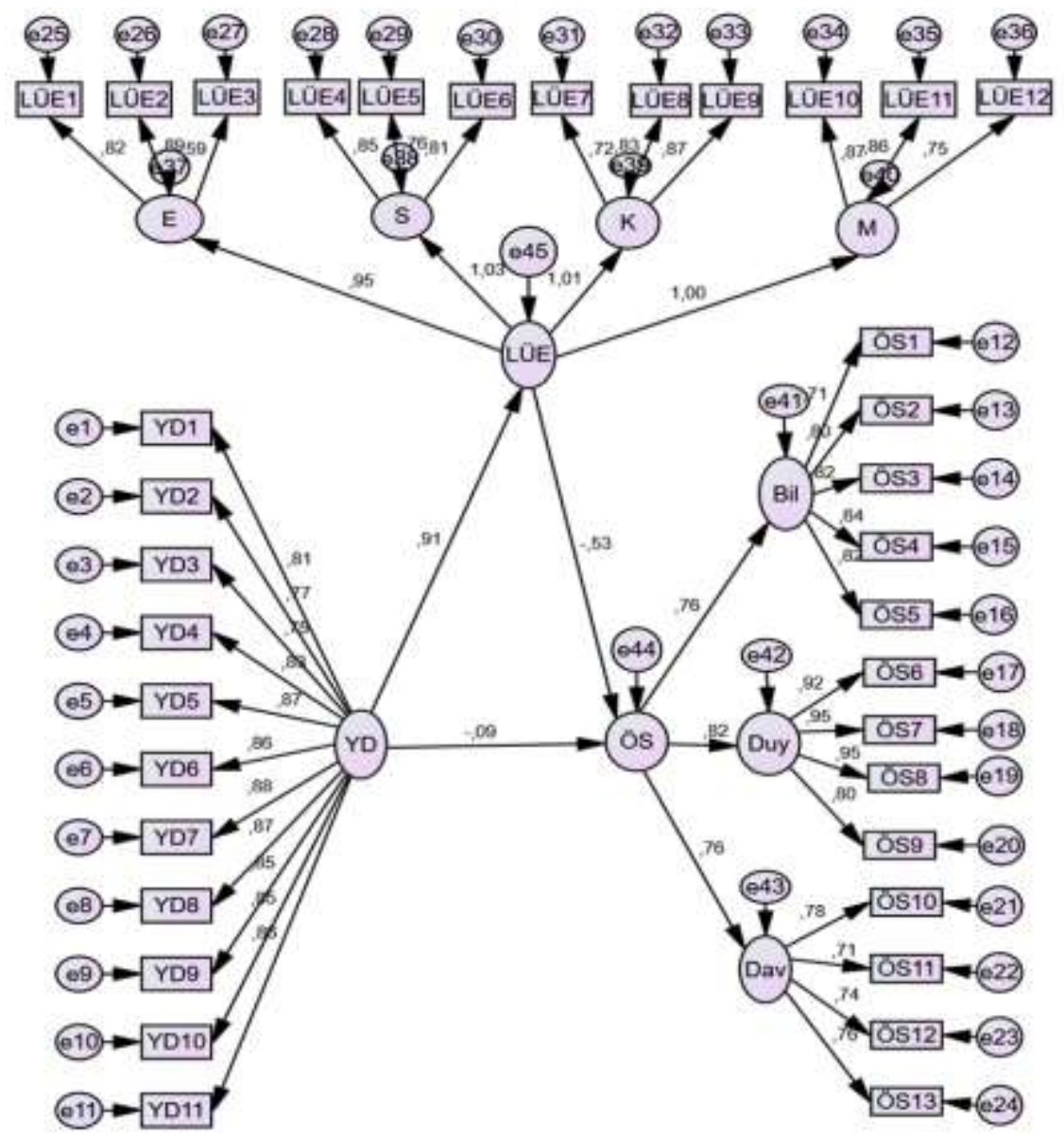

Şekil 4. İkinci yapısal eşitlik modellemesi ${ }^{4}$

\footnotetext{
${ }^{4}$ Notlar: Şekilde okların üzerinde gösterilen değerler noktadan sonraki rakamların iki basamağa yuvarlandığı standardize edilmiș regresyon katsayılarıdır. Kısaltmalar: YD: Algılanan Yönetici Desteği; LÜE: LiderÜye Etkileşimi; E:Etki; S:Sadakat; K:Katkı; M: Mesleki Saygı; Ös: Örgütsel Sinizm; Bil: Bilişsel; Duy: Duyuşsal; Dav: Davranısssal.
} 
Tablo 2'deki eşik değerler ile ikinci modele ilişkin hesaplanan değerler $\left[\Delta \mathrm{X}^{2} / \mathrm{sd}=1.883, \mathrm{CFI}=.927\right.$, TLI=.921, RMSEA $=.064$, HOELTER.05=125] karşlaştırıldığında, tüm uyum indeks değerlerinin yeterli düzeyde olduğu görülmektedir. Söz konusu uyum indeks değerleri dikkate alınarak ikinci modeldeki hiçbir ölçek maddesinin hata terimi başka bir ölçek maddesinin hata terimiyle birleştirilmeden ve herhangi bir ölçek maddesi analiz dışında bırakılmadan çalışmaya devam edilmiştir. İkinci yapısal eşitlik modellemesi sonuçlarına göre; algılanan yönetici desteği lider-üye etkileşiminin kalitesini anlamlı ve pozitif bir şekilde etkilerken $(\beta=0.912$; $\mathrm{p}<0.01)$, lider-üye etkileşiminin kalitesi örgütsel sinizmi anlamlı ve negatif bir şekilde etkilemektedir $(\beta=-0.526 ; p<0.01)$. $O$ halde; aracılığa ilişkin ikinci ve üçüncü koşullar sağlanmıştır. Algılanan yönetici desteğinin örgütsel sinizm üzerindeki etkisi ise anlamsızlaşmaktadır $(\beta=-0.091 ; p>0.05)$. $\mathrm{Bu}$ durum lider-üye etkileşiminin tam aracılık rolüne işaret etmektedir. $\mathrm{O}$ halde; aracılığa ilişkin dördüncü koşul da sağlanmıştır.

Aracılığa ilişkin dört koşul yapısal eşitlik modellemesiyle sağlandıktan sonra, son olarak aracılık etkilerinin anlamlı olup olmadığının belirlenmesi amaciyla Sobel testi yapılmıştır. Sobel testi sonucunda (Preacher ve Leonardelli, 2010); algılanan yönetici desteği ile örgütsel sinizm arasındaki ilişkiye lider-üye etkileşiminin aracılık yaptığ 1 tespit edilmiştir ( $\mathrm{z}=-$ 2.657; $\mathrm{p}<0.01)$. Dolayısıyla araştırma hipotezi desteklenmiştir. Ayrıca kurulan bu mekanizmada lider-üye etkileşimi değişkeni tam aracılık rolüne sahiptir.

\section{Tartışma ve Sonuç}

Literatürde; algılanan yönetici desteği ve lider-üye etkileşiminin kalitesi örgüte katkı sağlayan, örgütsel sinizm ise örgüte zarar veren unsurlar olarak görülmektedir. Sinizmin örgütlere zarar veren bir unsur olması sebebiyle örgütlerde sinizm ile mücadele edilmelidir. Bireylerde sinizm; hem doğuştan gelmekte hem de sonradan ortaya çıkabilmektedir. Bireylerde sinizmin doğuştan gelen tarafları olduğu dikkate alındığında, sinik bireylerin kişilik testleri, mülakatlar, gözlemler ve kişinin geçmişine dayalı araştırmalar yoluyla tespit edilerek işe alınmamasında fayda görülmektedir. Bireylerde sinizmin sonradan ortaya çıan tarafları da olduğu dikkate 
alındığında ise örgütlerde üst yönetimin aldığı kararların ve insan kaynakları departmanı uygulamalarının örgütsel sinizm düzeyi üzerinde etkili olacağı açıktır. Doğuştan sinik olmayan bireylerde de örgütlerdeki adil olmayan ve tutarsiz kararlar/uygulamalar sonucunda sinik tutum ve davranışlar ortaya çıkabilmektedir.

Çalışma kapsamında örgütlerde sinizm ile mücadele edilmesi bağlamında; algılanan yönetici desteği ile örgütsel sinizmin arasındaki ilişkide lider-üye etkileşiminin aracılık rolü incelenmiştir. Literatür taramasında; ilgili değişkenler arasındaki ilişkileri aynı kurguda (mekanizmada) inceleyen başka bir çalışmaya rastlanmamıştır.

Bu çalışmada; araştırma modelinde yer alan tüm değişkenlerin düzeyleri ast konumundaki çalışanların algıları üzerinden hesaplanmıştır. Algı üzerinden belirlenen tüm değişken düzeylerinin gerçeği yansıttığı varsayılmaktadır. Analiz sonuçlarına göre, çalışmaya katılanlar bakımından; beklenildiği gibi algılanan yönetici desteği ile lider-üye etkileşiminin kalitesi arasında anlamlı ve pozitif bir ilişki, hem algılanan yönetici desteği hem de lider-üye etkileşiminin kalitesiyle örgütsel sinizm arasında ise anlamlı ve negatif ilişkiler olduğu tespit edilmiştir. Lider-üye etkileşimi değişkeni; algılanan yönetici desteği ile örgütsel sinizm arasındaki ilişkide tam aracı değişken rolüne sahiptir. O halde; algılanan yönetici desteği düzeyi arttı̆̆ında lider-üye etkileşiminin kalitesi de artmakta, lider-üye etkileşiminin kalitesindeki artış ise örgütsel sinizmi azaltmaktadır. Bununla birlikte algılanan yönetici desteği, örgütsel sinizmi sadece lider-üye etkileşiminin kalitesi üzerinden dolaylı olarak etkileyebilmektedir. Diğer bir ifadeyle algılanan yönetici desteği düzeyi arttığında örgütsel sinizmin azalabilmesi için lider-üye etkileşiminin kalitesinin de mutlaka yükselmesi gerekmektedir.

Tüm bu bilgiler ışığında, çalışma kapsamında; algılanan yönetici desteği ve lider-üye etkileşiminin kalitesi düzeylerindeki artışın örgütsel sinizm düzeyi üzerindeki azaltıcı etkileri yoluyla örgütsel sinizmin örgüt üzerindeki zarar verici etkilerini düşürmenin ve böylece örgüte katkı sağlamanın mümkün olduğu sonucuna ulaşılmaktadır. Örgütsel sinizmin azaltılması bağlamında; yöneticilerin astlarına bilgisel, duygusal ve maddi anlamda verecekleri destek yanında, yönetici-ast arasındaki karş1lıklı ilişkide yani etkileşimde hem yöneticinin hem de astın tutum ve davranışları önem arz etmektedir. 
Lider-üye etkileşimi teorisine göre; liderin iç gruba dahil ettiği çalışanlarla karşılıklı ilişkisinin yani etkileşiminin kalitesi dış gruptan daha yüksektir. O halde; astların iç grup içerisinde yer alması lider-üye etkileşimi kalitesini yükseltmektedir. Ancak liderin iç grup için belirlediği bireyleri neye göre seçtiği çok açı değildir. Liderin kendi sahip olduğu özellikleri (yaş, cinsiyet, eğitim, kişilik vs.) taşıyan kişileri iç gruba dahil ettiği düşünülmektedir (Ergeneli, 2006, s.229-230). Bu konu hakkında daha fazla çalışma yapılması gerekmektedir. Bu kapsamda gelecekteki çalışmalarda; bu çalışmanın araştırma modeline ast konumunda çalışanların kişisel özellikleri (yaşı, cinsiyeti, eğitim düzeyi gibi demografik özellikleri ve kişilik özellikleri) düzenleyici değişken olarak eklenmek suretiyle araştırma modeli genişletilebilir. Ayrıca çalışma kamu sektöründe görev yapan mühendisler üzerinde gerçekleştirilmiştir. Araştırmanın evreninde erkek sayısı kadın sayısından çok daha fazladır ve 18-28 yaş aralığında çalışan sayısı çok düşüktür. Aynı araştırma modeli; özel sektörde, kadın-erkek sayısının daha dengeli dağıldığı ya da kadın sayısının daha fazla olduğu farklı meslek gruplarında, 18-28 yaş aralığındaki çalışan sayısının daha yüksek bir yüzdeye sahip olduğu bir örneklemde ve Türk kültüründen farklı özelliklere sahip olan batı ve uzak doğu kültürlerinde de test edilerek sonuçlar karşılaştırılabilir. 


\title{
EXTENDED ABSTRACT
}

\section{The Mediating Effect of Leader-Member Exchange in the Relationship Between Perceived Supervisor Sup- port and Organizational Cynicism}

\author{
Zülfi Umut Özkara - Aynur Taş - Belgin Aydıntan \\ Ankara Hacı Bayram Veli University - Hakkari University - Ankara Hacı Bayram Veli University
}

The primary goal of this study is to investigate the mediating effect of the leader-member exchange in the relationship between the perceived supervisor support and the organizational cynicism. There are many studies in the field of organizational behavior about the subjects of perceived supervisor support, leader-member exchange and organizational cynicism in both domestic and foreign literature. In the literature, while the perceived supervisor support and the quality of leader-member exchange are considered as the element contributing to the organisation, organizational cynicism is regarded as a damaging element for the organisation. In this regard, it is sought an answer to the question of "is it possible to reduce the damaging effects of organizational cynicism on the organization and thus contribute to the organization through the reducing effects of the increase in the levels of the perceived supervisor support and the quality of leader-member exchange on the level of organisational cynicism?"

The studies investigating the mediating effect of leader-member (supervisor-subordinate) exchange in the relationships among the variables of perceived supervisor (leader) support and, pro-environmental behaviour (Gkorezis, 2015) and job performances of employees (Akkoç et al., 2013; Karayel, 2016) have been detected. In this study, the organisational cynicism has been used as an outcome variable in the research model as different from other studies.

It can be stated that this study bases on Social Exchange Theory (Blau, 1964). The Social Exchange Theory grounds on the Norm of Reciprocity (Gouldner, 1960). According to Settoon et al. (1996), positive and beneficial actions between supervisor and employee provide a high-quality tradeoff relationship by creating the feeling of obligation between the parties. 
It is expected within the scope of this study that in the case that the employees' perception towards taking support from their supervisors in informational, emotional and financial respects increase, the quality of interrelationship between supervisor-subordinate, in other words interaction, would rise and thus the cynical, in other words negative, attitudes of employees towards their organisation would decrease.

Supervisor support can be defined as "supervisors' supporting their employees, showing interest in them, motivating them in achieving their goals by encouraging" (Babin and Boles, 1996, p.60). The leader-member exchange theory examines the relationships between the leader and members as bidirectional. In other words, this theory analyses the bilateral relationships, that is exchange, between the leader (supervisor) and member (subordinate) (Gültekin, 2014, p.31). While the subordinates think that they are supported by their supervisors at lower level in a low-quality relationship established between leader (supervisor) and member (subordinate), they consider that they are supported by their supervisors at higher level in a high-quality relationship established between leader (supervisor) and member (subordinate) (Çalışkan, 2009). In the study conducted by Chen et al. (2008), while increase in the quality of leader-member exchange has raised the perceived supervisor support, other studies in the literature (Akkoç et al., 2013; Gkorezis, 2015; Karayel, 2016) urge that increase in the level of perceived supervisor support has raised the quality of leadermember exchange.

Organisational cynicism means the negative feeling, attitude and behaviours of employees that they have developed towards their organisations due to their belief of organisations' being deprived of honesty (integrity) (Dean et al., 1998, p.345). The perceived supervisor support has significant and negative relationships with employee cynicism in the study carried out by Cole et al. (2006) in Germany and with organisational cynicism in the study administrated by Neves (2012) in Portugal. Ece et al. (2018) found out in their research on the employees of the public institution of Düzce Province that increase in the level of perceived supervisor support reduced the level of organisational cynicism. It was revealed by Gkorezis (2015) in his study on the public employee in Greece, and by Gültekin (2014) in her study on academic and administrative staff working in 
state universities in Turkey that increase in the quality of leader-member exchange reduced organisational cynicism.

The research model of the study (see Appendix 1) was established and its hypothesis was developed based on theoretical information and empirical studies in the literature.

Hypothesis: The leader-member exchange has mediating effect on the relationship between the perceived supervisor support and the organisational cynicism.

The population of research includes 401 engineers working in the central organization of a public institution in Ankara. The data set size of this study, in which data was obtained through questionnaire method, is 215. The questionnaire form consists of four sections. These sections are as follow: the first section included a scale of 11 items developed by Giray and Şahin (2012) to measure the perceived supervisor support; the second section involved a scale of 12 items with four dimensions of 3 items for effect, 3 items for loyalty, 3 items for contribution and 3 items for professional respect developed by Liden and Maslyn (1998); the third section consisted of a scale of 13 items with three dimensions of 5 items for cognitive, 4 items for affective and 4 items for behavioural aspects developed by Brandes, Dharwardkar and Dean (1999) in order to determine cynical attitude in terms of organisation. The scoring of these scales was graded as "1" (strongly disagree) and " 5 " (strongly agree) in 5-point Likert-type measurement level. The participants were finally asked to respond to some demographic questions such as gender, age, education level and working time in the institution in the fourth section.

The data was collected through questionnaire method in this study designed as a quantitative research. First, data were entered using SPSS 24 program. Demographic characteristics of the participants were determined after the data set was checked and prepared for the analysis (preliminary analyses). Next, the construct validity of the research model was tested with confirmatory factor analysis (CFA) by using the AMOS 24 program. Following this, the mean and standard deviation values of the variables in the research model were calculated and, reliability and Pearson correlation analyses were performed using the "SPSS 24" program. After the research hypothesis was tested with structural equation modeling 
(SEM) using AMOS 24 program and it was finally analysed by Sobel test in interactive environment.

$20.0 \%$ of the employees, who participated in the study, are women and $80.0 \%$ of them are men. The number of female engineers working in the institution is less than that of men. This is seen in the data set of research. It also indicates that very few engineers have been employed by the state in this institution especially in recent years since only $4.2 \%$ of all participants are in the age range of 18-28 and the number of employee working at the institution for less than 1 year is " 0 ".

Overall confirmatory factor analysis was administrated for the research model of the study by using the method of maximum likelihood (Anderson and Gerbing, 1988). The lowest factor load value was determined as ".59" within the scope of the study and this value is regarded as acceptable (Hair et al., 2010). What is more, it can be stated that all the fit index values calculated for the measurement model of the study are adequate $\left[\Delta \mathrm{X}^{2} / \mathrm{sd}=1.883, \mathrm{CFI}=.927, \quad \mathrm{TLI}=.921, \quad \mathrm{RMSEA}=.064\right.$, HOELTER.05=125] (Hair et al., 2010; Meydan and Şeşen, 2011). The lowest reliability coefficient value of the variables included in the study was calculated as ". 80 ". This value's being higher than the value suggested by Hair et al. (2010), in other words ".70", shows that the scales used in this investigation are reliable. It was detected as a result of correlation analysis administrated and in parallel to the theoretical and empirical studies in the literature that there were positive and significant relationship ( $\mathrm{r}=0.87$, $\mathrm{p}<.01)$ between the perceived supervisor support and leader-member exchange; a negative and significant relationship between the perceived supervisor support and organisational cynicism $(\mathrm{r}=-0.49, \mathrm{p}<.01)$; and a negative and significant relationship between the quality of leader-member exchange and organisational cynicism $(\mathrm{r}=-0.52, \mathrm{p}<.01)$.

In the literature, while the perceived supervisor support and the quality of leader-member exchange are considered as the element contributing to the organisation, organizational cynicism is regarded as damaging element to the organisation. It should be fought with cynicism in the organisation since it is a damaging element for organisations. Cynicism in individuals may be both innate and occur later. Considering the innate aspects of cynicism in individuals, it is considered as beneficial not to employ the 
cynical individuals by detecting them through personality tests, interviews, observations and research based on the background of that individual. In addition, when considering the aspects of cynicism in individuals that may occur later, it is clear that the decisions taken by senior management and the implementations of human resources department will be effective on the level of organisational cynicism. Cynical attitudes and behaviours may also be seen in individuals, who do not have innate cynicism, as a result of unfair and inconsistent the decisions/implementations in organisations. In this study, the mediating role of leader-member exchange has been investigated in the relationship between the perceived supervisor support and organisational cynicism within the scope of fighting with cynicism in organisations.

In this study, the process suggested by Meydan and Şeşen (2011) for the purpose of researching mediation has been followed. This process bases on the method used by Baron and Kenny (1986) when performing classic regression analysis. The calculated fit index values of the first model established (including only independent and dependent variables) are adequate $\left[\Delta \mathrm{X}^{2} / \mathrm{sd} \quad=1.894, \quad \mathrm{CFI}=.949, \quad \mathrm{TLI}=.943, \quad \mathrm{RMSEA}=.065\right.$, HOELTER.05=131]. According to the results of the first structural equation modeling seen in Appendix 1, the perceived supervisor support affects organisational cynicism negatively and significantly $(\beta=-0.572 ; p<0.01)$. Accordingly, the first condition of mediation has been met. It can also be stated that the calculated fit index values of the second model established (including the mediating variable and being the research model of the study) are adequate $\left[\Delta \mathrm{X}^{2} / \mathrm{sd}=1.883, \mathrm{CFI}=.927, \mathrm{TLI}=.921\right.$, RMSEA $=.064$, HOELTER.05=125]. Therefore, according to the results of validity, reliability and the first and second structural equation modeling, the study continued without unifying the error term of any scale item with the error term of another scale item in the research model and without excluding any scale item out of the analysis. According to the results of the second structural equation modeling seen in Appendix 1, while the perceived supervisor support affects the quality of leader-member exchange significantly and positively $(\beta=0.912 ; p<0.01)$, the quality of leader-member exchange affects organisational cynicism significantly and negatively $(\beta=-$ 0.526; $\mathrm{p}<0.01)$. For this reason, the second and third conditions of media- 
tion have been met. The effect of the perceived supervisor support on organisational cynicism gets insignificant $(\beta=-0.091 ; \mathrm{p}>0.05)$. This indicates the full mediation role of leader-member exchange. Thus, the fourth condition of mediation has been met. After four conditions of mediation have been met through the structural equation modeling, Sobel test has been finally administrated so as to determine whether mediation effects are significant or not. It has been found out as a result of Sobel test (Preacher and Leonardelli, 2010) that the leader-member exchange mediated to the relationship between the perceived supervisor support and organisational cynicism $(\mathrm{z}=-2.657 ; \mathrm{p}<0.01)$. Accordingly, the research hypothesis has been supported. In addition, the variable of leader-member exchange has full mediation role in this mechanism established. In this manner, the quality of leader-member exchange increases as the level of perceived supervisor support raises, and the increase in the quality of leader-member exchange reduces organisational cynicism. Moreover, the perceived supervisor support can only affect organisational cynicism indirectly over the quality of leader-member exchange. In other words, the quality of leader-member exchange must necessarily increase for organisational cynicism may reduce when the perceived supervisor support increases.

In the light of all mentioned information and within the scope of this study, it is achieved to the result that it is possible to reduce the damaging effects of organizational cynicism on the organization and thus contribute to the organization by reducing the level of organizational cynicism through the increase in levels of the perceived supervisor support and the quality of leader-member exchange. The attitudes and behaviours of both supervisor and subordinate have importance in the interrelationship, in other words exchange, between supervisor-subordinate besides the support that manager would give to their subordinates in informational, emotional and financial respects within the context of reducing organisational cynicism.

This research model may be extended by adding the personal characteristics (demographic characteristics such as age, gender, education level and personality traits) of employees working in the position of subordinate as a moderator to the research model of this study for further research. In addition, this study has been conducted on engineers working in the public sector. The number of men in the population of the research 
is more than the number of women and the number of employees aged 18-28 is very low. The same research model may be tested in the private sector, in different occupational groups in which the number of womanman has been distributed in more balanced or the number of women is higher; in a sample with a higher percentage of employees between the age range of 18-28, and in western and far eastern cultures having different characteristics different from Turkish culture, and the results to be obtained may be compared.

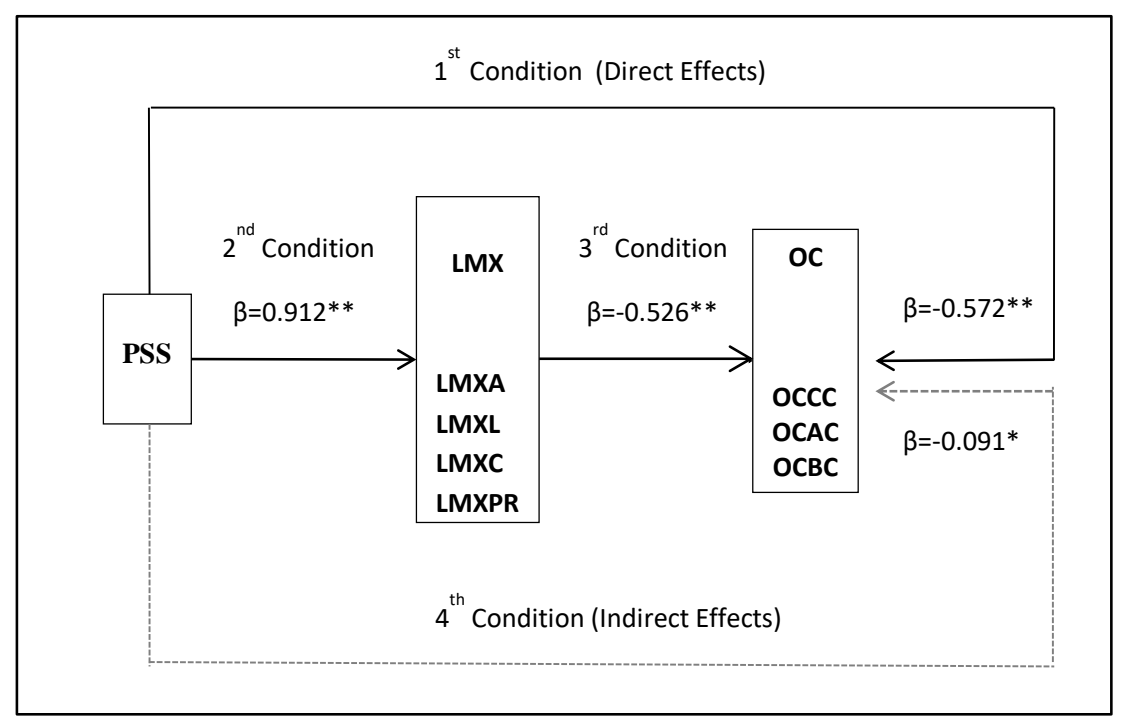

Appendix 1 - The Summary of SEM Results (The Research Model of the Study)

\footnotetext{
${ }^{5}$ Notes: ${ }^{* *} p<0.01,{ }^{*} p>0.05 ; 6=$ Standardized regression coefficient; Abbreviations: PSS: Perceived Supervisor Support; LMX: Leader-Member Exchange; LMXA: Affect Dimension of Leader-Member Exchange; LMXL: Loyalty Dimension of Leader-Member Exchange; LMXC: Contribution Dimension of Leader-Member Exchange; LMXPR: Professional Respect Dimension of Leader-Member Exchange; OC: Organizational Cynicism; OCCC: Cognitive/Belief-Based Cynicism Dimension of Organizational Cynicism; OCAC: Affective/Affect-Based Cynicism Dimension of Organizational Cynicism; OCBC: Behavioural Cynicism Dimension of Organizational Cynicism.
} 


\section{Kaynakça / References}

Akkoç, İ., Çalışkan, A., Uçak, P. ve Özalp, D. (2013). Örgütsel destek, lider ve sosyal desteğin iş performansına etkisinde lider-üye etkileşiminin rolü. 21. Ulusal Yönetim ve Organizasyon Kongresi Bildiriler Kitabı içinde (s. 205-207), 30 Mayıs-1 Haziran, Dumlupınar Üniversitesi İ̈BF, Kütahya.

Anderson, J.C. ve Gerbing, D.W. (1988). Structural equation modeling in practice: A review and recommended two-step approach. Psychological Bulletin, 103(3), 411-423.

Andersson, L.M. ve Bateman, T.S. (1997). Cynicism in the workplace: Some causes and effects. Journal of Organizational Behavior, 18(5), 449-469.

Azman, I., Sieng, L.L.C., Ajis, M.N., Dollah, N.F. ve Boerhannoeddin, A. (2009). Relationship between supervisor's role and job performance in the workplace training program. Ştiinte Economice, 56, 237-251.

Babin, B.J. ve Boles, J.S. (1996). The effects of perceived co-worker involvement and supervisor support on service provider role stress, performance and job satisfaction. Journal of Retailing, 72(1), 57-75.

Bardakoğlu, Ö., Akgündüz, Y., Kızılcalığlu, G. ve Yeşilyurt, H. (2017). Otel işletmelerinde algılanan yönetici desteğinin çalışanların iş stresi ve mutluluk düzeylerine etkisi. 8. Uluslararası Girişimcilik Kongresi Bildiriler Kitabı içinde (s. 103-116), 14-16 Temmuz, Balıkesir Üniversitesi, Balıkesir.

Baron, R.M. ve Kenny, D.A. (1986). The moderator-mediator variable distinction in social pychological research: Conceptual, strategic, and statistical considerations. Journal of Personality and Social Psycho$\log y, 51(6), 1173-1182$.

Bentler, P.M. ve Bonett, D.G. (1980). Significance tests and goodness of fit in the analysis of covariance structures. Psychological Bulletin, 88(3), 588-606. 
Bhanthumnavin, D. (2000). Importance of supervisory social support and its implications for HRD in thailand. Psychology and Developing Societies, 12(2), 155-166.

Bhanthumnavin, D. (2003). Perceived social support from supervisor and group members' psychological and situational characteristics as predictors of subordinate performance in Thai work units. Human Resource Development Quarterly, 14(1), 79-97.

Blau, P.M. (1964). Exchange and power in social life. NY: John Wiley \& Sons. Brandes, P., Dharwadkar, R. ve Dean, J.W. (1999). Does organizational cynicism matter? Employee and supervisor perspectives on work outcomes. Eastern Academy of Management Proceedings, Philadelphia, 150-153.

Browne, M.W. ve Cudeck, R. (1993). Alternative ways of assessing model fit. K.A. Bollen ve J.S. Long (Eds.), Testing structural equation models içinde (s. 136-162), California: Thousand Oaks, Sage, Newbury Park.

Büyüköztürk, Ş. (2012). Sosyal bilimler için veri analizi el kitabı (17. Baskı). Ankara: Pegem Akademi.

Chen, C.H.V., Wang, S.J., Chang, W.C. ve Hu, C.S. (2008). The effect of leader-member exchange, trust, supervisor support on organizational citizenship behavior in nurses. Journal of Nursing Research, 16(4), 321-328.

Cole, M,S., Brunch, H. ve Vogel, B. (2006). Emotion as mediators of the relations between perceived supervision support and psychological hardiness on employee cynicism. Journal of Organizational Behavior, 27, 463-484.

Çalışkan, S.C. (2009). Turizm işletmelerinde liderlik tarzları ve lider-üye etkileşimi kalitesi (LÜE) üzerine bir çalışma. Trakya Üniversitesi Sosyal Bilimler Dergisi, 11(2), 219-241.

Davis, W.D. ve Gardner, W.L. (2004). Perception of politics and organizational cynicism: An attributional and leader-member exchange perspective. The Leadership Quarterly, 15, 439-465.

Dean, J.W., Brandes, P. ve Dharwadkar R. (1998). Organizational cynicism. The Academy of Management Review, 23(2), 341-352. 
De-Bakker, E. (2007). Integrity and cynicism: Possibilities and constraints of moral communication. Journal of Agricultural and Environmental Ethics, 20(1), 119-136.

Eaton, J. A., (2000). A social motivation approach to organizational cynicism. Yüksek lisans tezi, York Üniversitesi, Psikoloji Program1, Toronto, Ontario.

Ece, S., Kurban, Z. ve Gültekin, S. (2018). Öz-yeterlik alg1Sı ve örgütsel sinizm ilişkisi: Algılanan yönetici desteğinin aracilık rolü. Anemon Muş Alparslan Üniversitesi Sosyal Bilimler Dergisi, 6(6), 993-1000.

Emhan, A., Kula, S. ve Töngür, A. (2013). Yapısal eşitlik modeli kullanılarak yönetici desteği, örgütsel bağlllık, örgütsel performans ve tükenmişlik kavramları arasındaki ilişkilerin analizi: Kamu sektöründe bir uygulama. Hacettepe Üniversitesi İktisadi ve İdari Bilimler Fakültesi Dergisi, 31(1), 53-69.

Ergeneli, A. (2006). Örgüt ve insan (1. Baskı). Ankara: Hacettepe Üniversitesi Yayınları.

Fitzgerald, M.R. (2002). Organizational cynicism: Its relationship perceived organizational injustice explanatory style. Doktora tezi, University of Cincinnati, Arts and Sciences, Ohio.

Giray, M.D. ve Şahin, D.N. (2012). Algılanan örgütsel, yönetici ve çalışma arkadaşları desteği ölçekleri: Geçerlik ve güvenirlik çalışması. Türk Psikoloji Yazıları, 15(30), 1-9.

Gkorezis, P. (2015). Supervisor support and pro-environmental behavior: The mediating role of LMX. Management Decision, 53(5), 1045-1060.

Gouldner, A.W. (1960). The norm of reciprocity: A preliminary statement. American Sociological Review, 25(2), 161-178.

Graen, G.B. ve Scandura, T.A. (1987). Toward a psychology of dyadic organizing. Research in Organizational Behavior, 9, 175-208.

Gültekin, S. (2014). Psikolojik sözleşme ihlali ile örgüte karşı sinik tutum arasındaki iliş̧ide lider-üye etkileşiminin aracılık etkisi. Doktora tezi, Hacettepe Üniversitesi, Sosyal Bilimler Enstitüsü, Ankara.

Hair, J.F., Black, W.C., Babin, B.J. ve Anderson, R.E. (2010). Multivariate data analysis (7. Baskı). NJ: Pearson Prentice Hall, Upper Saddle River. 
Hu, L. ve Bentler, P. (1995). Evaluating model fit. R.H. Hoyle (Ed.), Structural equation modeling: Concepts, issue, and applications içinde (s. 7699), California: Sage Publications, Newbury Park.

Hu, L. ve Bentler, P.M. (1999). Cutoff criteria for fit indexes in covariance structure analysis: Conventional criteria versus new alternatives. Structural Equation Modeling: A Multidisciplinary Journal, 6(1), 1-55.

İnce, F. (2018). Örgütsel sinizm. E. Aydoğan (Ed.), Örgütsel davranış odaklı yönetsel yaklaşımlar içinde (s. 509-518), Ankara: Gazi Kitabevi.

James, M.S.L. (2005). Antecedents and consequences of cynicism in organizations: An examination of the potential positive and negative effects on school systems. Doktora tezi, The Florida State University, College of Business, Florida.

Johnson, J.L. ve O'Leary-Kelly, A.M. (2003). The effects of psychological contract breach and organizational cynicism: Not all social exchange violations are created equal. Journal of Organizational, 24(5), 627-647.

Kahn, R.L., Wolfe, D.M., Quinn, R.P., Snoek, J.D. ve Rosenthal, R.A. (1965). Organizational stress: Studies in role conflict and ambiguity. Administrative Science Quarterly, 10(1), 125-129.

Kalaycı, Ş. (2010). SPSS uygulamalı çok değiş̧kenli istatistik teknikleri. Ankara: Asil Yayınevi.

Karayel, M. (2016). Örgütsel destek, lider desteği ve sosyal desteğin iş performansina etkisinde lider-üye etkileşiminin aracılık rolü: Yerel yönetimler örneği. Yüksek lisans tezi, Türk Hava Kurumu Üniversitesi, Sosyal Bilimler Enstitüsü, Ankara.

Khalid, A., Rathore, K. ve Aslam, N. (2017). The influence of supervisory support on work motivation: A moderating role of organizational support. New Trends and Issues Proceedings on Humanities and Social Sciences, 4(10), 136-143.

Kline, R.B. (2005). Principles and practice of structural equation modeling (2. Bask1). NY: The Guilford Press.

Liden, R.C. ve Maslyn, J.M. (1998). Multidimensionality of leader-member exchange: An empirical assessment through scale development. Journal of Management, 24(1), 43-72.

Liden, R.C., Sparrowe, R.T. ve Wayne, S.J. (1997). Leader-member exchange theory: The past and potential for the future. G. Ferris 
(Ed.), Research in personnel and human resource management içinde (s. 47-119), 15, Greenwhich: JAI Press.

Maslyn, J.M. ve Uhl-Bien, M. (2001). Leader-member exchange and its dimensions: Effects of self-effort and other's effort on relationship quality. Journal of Applied Psychology, 86(4), 697-708.

Meydan, C.H. ve Şeşen, H. (2011). Yapısal eşitlik modellemesi: Amos uygulamaları (1. Baskı). Ankara: Detay Yayıncılık.

Neves, P. (2012). Organizational cynicism: Spillover effects on supervisorsubordinate relationships and performance. The Leadership Quarterly, 23, 965-976.

Newman, A., Thanacoody, R. ve Hui, W. (2012). The effects of perceived organizational support, perceived supervisor support and intraorganizational network resources on turnover intentions. Personnel Review, 41(1), 56-72.

Özutku, H., Ağca, V. ve Cevrioğlu, E. (2008). Lider-üye etkileşim teorisi çerçevesinde, yönetici-ast etkileşimi ile örgütsel bağlılık boyutları ve iş performansı arasındaki ilişki: Ampirik bir inceleme. İktisadi ve İdari Bilimler Dergisi, 22(2), 193-210.

Pohl, S. ve Galletta, M. (2016). The role of supervisor emotional support on individual job satisfaction: A multilevel analysis. Applied Nursing Research, 33, 61-66.

Preacher, K.J. ve Leonardelli, G.J. (2010). Calculation for the sobel test: An interactive calculation tool for mediation tests, 31 Ocak 2019 tarihinde http://www.quantpsy.org/sobel/sobel.htm adresinden erişildi.

Qureshi, M.A. ve Hamid, K. (2017). Impact of supervisor support on job satisfaction: A moderating role of fairness perception. International Journal of Academic Research in Business and Social Sciences, 7(3), 235242.

Robbins, S.P. ve Judge, T.A. (2013). Liderlik (14. Baskıdan Çeviri). A. Yalçın (Ed.), İ. Erdem (Çev. Ed.), Örgütsel davranış içinde (s. 374-416), Ankara: Nobel Akademik Yayıncilık.

Salahian, A., Oreizi, H.R., Abedi, M.R. ve Soltani, I. (2012). Co-workers/supervisor support and burnout. Interdisciplinary Journal of Contemporary Research in Business, 4(1), 141-148.

Setton, R.P., Bennett, N. ve Liden, R.C. (1996). Social exchange in organizations: Perceived organizational support, leader-member 
exchange, and employee reciprocity. Journal of Applied Psychology, 81(3), 219-227.

Tabachnick, B.G. ve Fidell, L.S. (2013). Using multivariate statistics (6. Baskı), Boston: Allyn \& Bacon.

Taş, A. ve Özkara, Z.U. (2018). Algılanan yönetici desteği ile işten ayrılma niyeti arasındaki ilişkide iş stresinin aracılık rolü. 6. Örgütsel Davranış Kongresi Bildiriler Kitabı içinde (s. 510-519), 2-3 Kasım, Süleyman Demirel Üniversitesi, Isparta.

Van Breukelen, W., Schyns, B. ve Le Blanc, P. (2006). Leader-member exchange theory and research: Accomplishments and future challenges. Leadership, 2(3), 295-316.

Wang, Z. (2014). Perceived supervisor support and organizational citizenship behavior: The role of organizational commitment. International Journal of Business and Social Science, 5(1), 210-214.

Yoon, J. ve Lim, J. C. (1999). Organizational support in the workplace: The case of Korean hospital employees. Human Relations, 52(7), 923945.

\section{Kaynakça Bilgisi / Citation Information}

Özkara, Z. U., Taş, A. ve Aydıntan, B. (2019). Algılanan yönetici desteği ile örgütsel sinizm arasındaki ilişkide lider-üye etkileşiminin aracilık etkisi. OPUS-Uluslararası Toplum Araştırmaları Dergisi, 12(18. UİK Özel Sayısı), 101-137. DOI: 10.26466/opus.584036. 